\title{
The Nonmanufacturing Patent Owner: Toward a Theory of Efficient Infringement
}

\author{
Julie S. Turner $\dagger$
}

Patent law provides for injunctive relief against infringers. Courts rarely deny a patent owner's request for injunctive relief, regardless of the actual harm being suffered by the patent owner because of a presumption of irreparable harm in patent cases, a presumption seen as necessary to promote invention. This Comment explores the justifications and goals of the patent system as well as economic theories as applied to law, and argues that injunctive relief for intentionally nonmanufacturing patent owners is antithetical to the goals of the patent system and is economically inefficient as well. As a result, the Comment proposes a model of "efficient infringement," whereby the use of liability rules within the context of patent litigation will promote the commercialization of patents and concomitant wealth maximization.

\section{INTRODUCTION}

In the early 1970s, Roxy N. Fan, a scientist, secured a position in the research department of E. I. du Pont de Nemours and Company, one of the world's largest conglomerates. Shortly thereafter, Fan filed for her first patent, a Process For Image Reproduction Using Multilayer Photosensitive Solvent Processable Elements. The patent, which ultimately issued on October 11, 1977, was for a color proofing process. ${ }^{1}$ $\mathrm{Du}$ Pont was the assignee-at-issue for the patent. ${ }^{2}$

At about the same time as Fan was working on her color proof process, Daniel Spechler was in New Jersey working on a similar color proof process. Spechler was employed by Keuffel \& Esser Company and assigned to Keuffel \& Esser two patents dealing with color

\footnotetext{
Copyright $(\mathcal{C} 1998$ California Law Review, Inc.

$\dagger$ The author wishes to express her gratitude to Peter Menell, Julie Jauregui Holloway and Keri Frankel Klein for their insight, enthusiasm, encouragement, and hard work.

1. See U.S. Patent No. 4,053,313 (Oct. 11, 1977) [hereinafter Fan patent].

2. The prolific Fan has done well by Du Pont. Fan has assigned 28 patents to Du Pont over her tenure in its R\&D department; the most recent issued last year.
} 
proofing. ${ }^{3}$ One color proof process developed by Spechler was remarkably similar to Fan's, and ultimately drew the attention of Polaroid Corporation.

Color proofing is highly valued in the graphic arts industry because it provides an inexpensive check on the quality of color separations. Absent color proofing, the quality of color separations may be checked only when printing plates are prepared for the final printing. Mistakes at this point are very costly. By using a color proofing stage, printers are able to adjust the color separations before the printing plates are made, thus avoiding costly errors.

By the time Spechler applied for his patent, Fan's had already issued. Nevertheless, the Keuffel \& Esser Company, believing that Spechler was the first to invent, entered into an interference with Du Pont over the Fan patent. ${ }^{4}$ The interference was litigated for three years. In the end, Du Pont was victorious and the Fan patent, which had warranted an expensive interference proceeding, stood. ${ }^{5}$

Keuffel \& Esser fell on hard times. It was purchased by a company which itself suffered fimancial difficulties. The company ultimately sold Spechler's invention, now known as the Spectra Color Proofing System, to Sage Technology, which was owned in part by Polaroid. Du Pont had one of its attorneys notify Sage of the Fan patent.

Shortly thereafter, Polaroid acquired Sage and its rights to the Spectra process. Polaroid began marketing the valuable color proofing process. Sales in 1985 amounted to only $\$ 538,000$, but by 1987 , sales had reached about $\$ 3$ million, doubling to $\$ 6$ million in 1988 . The product was a commercial success. ${ }^{6}$

Du Pont did not sit back quietly while its Fan patent was infringed. Du Pont notified Polaroid of the patent, but Polaroid, having a winner on its hands, declared that it believed the Fan patent to be invalid on several grounds. Du Pont called for a reexamination and, on November 3,1987 , a reexamination certificate was issued which declared the patent valid as against prior art which Polaroid claimed invalidated the patent. In March of 1988, Du Pont notified Polaroid that the patent's validity had been reaffirmed. Nevertheless, Polaroid continued marketing its Spectra Color Proofing System. In May, Du Pont filed a patent infringement suit against Polaroid. In June, Du Pont sought to enjoin

3. See U.S. Patent No. 4,376,158 (Mar. 8, 1983) [hereinafter Spechler patent].

4. The United States patent system is a "first-to-invent" system; she who invented first in time may challenge a later inventor who is the first to file for a patent. This challenge is called an interference. In an interference, the first inventor seeks to prove his invention was first in time and that the later inventor should not be granted a patent.

5. See E.I. du Pont de Nemours \& Co. v. Polaroid Graphics Imaging, Inc., 706 F. Supp. 1135 , 1139 (D. Del.), affd, 887 F.2d 1095 (Fed. Cir. 1989).

6. See id. at 1145 n.13. 
Polaroid from marketing the Spectra system. In February, 1989, the United States District Court for the District of Delaware granted the injunction, effectively knocking Polaroid out of the color proofing market.

From the foregoing tale, it is obvious that the Fan patent was important to Du Pont. Patents are usually important to whoever owns them. Yet there is something quite unusual about the Fan story. Although almost all patent owners ${ }^{7}$ realize the commercial value of a patent through commercialization of the technology patented therein, the entire value of the Fan patent was to be realized from the refusal of the patent owner to permit commercialization. In other words, the Fan patent was worth more to $\mathrm{Du}$ Pont as a barrier to competition than for the technology disclosed. ${ }^{8}$ As it turns out, Du Pont had already commercialized a competing color proofing process, known as Cromalin. Du Pont's Cromalin process and the Matchprint process of Minnesota Manufacturing and Mining Company (3M) comprised approximately ninety percent of the color proofing market in the United States in 1989.' The color proofing process developed almost simultaneously by Fan and Spechler posed a competitive threat to the Cromalin process. Du Pont found it worth time and effort to: 1) conduct research leading to the Fan process; 2) patent the Fan process; 3) litigate a three-year interference over the Fan patent; 4) litigate through the preliminary injunction and appeal phase of an infringement suit over the Fan patent, and 5) bury the Fan patent for the remainder of its seventeen-year life in order to prevent competition with the Cromalin process in the color proofing market.

The only right the patent system bestows is the right to exclude others from making, selling, or using the subject matter of the patent. ${ }^{10}$ It is often said that the social value gained from conferring the limited

7. Technically, a "patentee" is the one who patents, always the inventor. The inventor may then assign the patent to an assignee or hicense the patcnt to a licensee. For purposes of this paper, the term "patent owner" is used to designate the entity that currently holds exclusive rights to the patent. Where distinction is necessary, the specific terms "inventor," "assignee," and "licensee" are used.

8. The fact that Du Pont seems to have made no offer of a license for the Fan patent to Polaroid or to any other company supports the conclusion that Du Pont intended to use the Fan patent as a market-entry barrier.

9. See Du Pont, 706 F. Supp. at 1145 n.15.

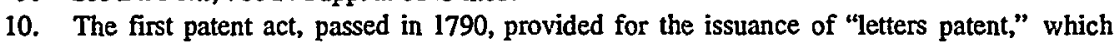
granted inventors "the sole and exclusive right and liberty of making, constructing, using and vending to others to be used" the patented invention, in exchange for full disclosure of the invention. Act of Apr. 10, 1790, ch. 7, §§ 1 \& 2, 1 Stat. 109 (1845); see also Eli Lilly \& Co. v. Medtronic, Inc., 496 U.S. 661,669 (1990) ("Under federal law, a patent 'grant[s] to the patentee, his heirs or assigns, for the term of seventcen years, ... the right to exclude others from making, using, or selling the invention throughout the United States."' (quoting 35 U.S.C. § 154)); Bloomer v. McQuewan, 55 U.S. 539, 549 (1852) ("The franchise which the patent grants, consists altogether in the right to exclude every one froin making, using, or vcnding the thing patented, without the permission of the patentee."). 
value of a monopoly is the required disclosure of the invention. ${ }^{11}$ Nevertheless, I contend that the patent system should not benefit those who would use a patent solely as a barrier to entry, without intent to pursue commercialization of the underlying technology-entities which I will call "nonmanufacturing patent owners." value, mere disclosure fails to justify the granting of a monopoly absent the patent owner's intent to commercialize the disclosed invention. As a result, the patent enforcement system should adopt a scheme whereby nonmanufacturing patent owners receive monetary relief equivalent to the "disclosure value" of their patents. ${ }^{13}$

In this Comment, I argue that in cases of infringement, the law should treat the nonmanufacturing owner of a commercially viable patent differently from other patent owners. Part I explores the phenomenon of nonmanufacturing patent owners. Part $I I$ explains how the nonuse of commercially viable patents conflicts with the justifications underlying the patent system. Part III argues that the goal of maximizing social welfare through promoting the sciences and useful arts might best be achieved through the imposition of liability, not property, rules when it comes to nonuse. Part IV offers a remedial proposal, namely the application of liability rules to the case of infringement against the nonmanufacturing patent owner, which the courts could enact under the current statutory patent scheme.

I

Why Patent Owners Have Incentives to "Sit" On Patent Rights

Patent owners fail to commercialize for five reasons. Three of these reasons are unrelated to anticompetitiveness and arise in situations that culminate in efficient outcomes, namely commercialization where practicable. First, the technology underlying the patent may not be commercially viable. Commercial nonviability may result when no current demand exists for the product, the cost of production under current technologies is prohibitively expensive, or the product's commercial

11. See, e.g., Bonito Boats, Inc. v. Thunder Craft Boats, Inc., 489 U.S. 141, 151 (1989) ("In consideration of its disclosure and the consequent benefit to the community, the patent is granted.") (quoting United States v. Dubilier Condenser Corp., 289 U.S. 178, 186-87 (1933)).

12. The term "nonmanufacturing patent owner" used in this sense is distinct from the inventor/patent owner who does not commercialize his product because it has no recognized commercial value, or whose attempts at commercialization have failed for one reason or another. This distinction is essential. See infra Part I.

13. This proposal may not seem to accord with 35 U.S.C. $\S 271$, which provides that "[n]o patent owner . . . shall be denied relief . . . by . . . refus[ing] to lieense or use any rights to the patent." 35 U.S.C.A. \& 271(d)(4) (West Supp. 1997). However, I do not propose that nonmanufacturing patent owners be denied all relief, only that equitable relief in the form of an injunction should be unavailable. See infra Part IV. 
viability is underestimated. ${ }^{14}$ In all of these cases, however, changes over time may transform a commercially unattractive patent into a winner.

Second, noncommercialization may occur where the technology, although commercially viable, constitutes a less promising development investment than other technologies that the patent owner is investigating. Noncommercialization of a commercially viable technology often results when a financially secure, research-intensive organization has a policy of patenting every patentable invention its researchers develop, regardless of the potential inarket for each invention. However, these companies are likely to subsequently license their "peripheral patents," patents which do not lie at the core of their commercial products or technologies.

Third, noncommercialization of a commercially viable technology may arise where the technology has no commercial applications in the patent owner's field. Again, once a different industry realizes the commercial value of the patent, licensing most usually results.

Two additional litigation-inducing reasons exist for failure to commercialize. First, the patent owner may set too high a price for licensing due to an improper valnation of his patent. Overvaluation is a natural response in the inexperienced inventor. Overvaluation may also occur when two experienced corporations hold blocking patents. ${ }^{15}$ Second, the patent owner may resist commercialization of the underlying technology because the resulting product would compete with a product the patent owner has already developed and commercialized. In this case, the patent owner will intentionally set an excessively high license price or will refuse to license, and will refuse to develop the underlying technology itself. ${ }^{16}$

14. For an overview of the nontechnical reasons driving the decision to forego commercialization of technology, see CENTRE FOR THE STUDY OF INDUSTRIAL INNOVATION, ON the Shelf: A Survey of Industrial R and D Projects Abandoned for Non-Technical REASONS (1971).

15. "Blocking patents" are essentially patents that cannot be used without the licensing of other patents. They most often occur between a pioneer patent and an improvement patent. See, e.g., Marconi Wireless Tel. Co. v. De Forest Radio Tel. \& Tel. Co., 236 F. 942 (S.D.N.Y. 1916) (finding an improvement patent on a triode infringed the patent on an evacuated container having two electrodes (diodes), since the triode patent necessarily contained two diodes; the triode patent owner thus must license the diode to use the triode invention, and diode patent owner must license the triode patent to use the improvement), aff'd, 243 F. 560 (2d Cir. 1917).

For a thoughtful proposal regarding the inability to negotiate cross-licenses between blocking patents, see Robert Merges, Intellectual Property Rights and Bargaining Breakdown: The Case of Blocking Patents, 62 TENN. L. REV. 75 (1994).

16. This was the case with patent No. 558,969, an improvement patent for paper bag manufacturing machines. See Continental Paper Bag Co. v. Eastern Paper Bag Co., 210 U.S. 405, 429-30 (1908). 
Economist Donald Schon provides an example of the second reason described above, the tendency of patent owners to avoid competing with themselves:

The research department of an appliance company developed a new means of preserving foods. It would have replaced conventional refrigerators. The sales department laughed the idea out of court. They already had 30 per cent of the refrigerator market: how could this new principle do anything but hurt their position? Their distributors were sold on the current line, understood the product, knew how to sell it. Why upset them? Millions had been imvested in establishing the firm name in refrigerators: why undercut that investment? ${ }^{17}$

At this point, Schon's hypothetical appliance company has two choices: it can put its new invention on a back burner within the company, maintaining it as an unused trade secret, or it can apply for a patent. The company recognizes that this invention could cut into its already profitable refrigerator business, for which the company has surely made large capital investments, not yet totally written off. The company decides to avoid the risk and expense inherent in developing and marketing this new technology. At the same time, the development and commercialization of the same technology by another company also would cut into the appliance company's refrigerator business. Finally, if a competitor were to patent its new technology, the competitor's patent might effectively foreclose the appliance company from entering into this potentially lucrative market. ${ }^{18}$

The invention of a potentially risky, potentially lucrative technology places Schon's appliance company at a crossroads. The company's choice whether to patent, and thus disclose the technology, will rely primarily on the company's appraisal of whether and when others are likely to make the same invention. Such a conclusion is logical given the following statutory requirements: (1) patent protection requires disclosure and (2) technology disclosed in patents becomes public domain

17. Donald A. Schon, Technology and Change 66 (1967). For an actual example of this type of corporate behavior, see McDonald v. Johnson \& Johnson, 537 F. Supp. 1282, 1306 (D. Minn. 1982) (finding that Johnson \& Johnson had purchased and fiscally starved a medical devices company that made transcutaneous electronic nerve stimulators, used to block pain, in order to prevent the growth and development of this therapy to avoid competition with its own drugs in the pain control field).

18. Naturally, the appliance company could assert a claim that it was the first to invent to prevent another company from patenting this new food preservation technology. However, the firstto-invent claim would only prevent patenting by another in the United States. All other developed countries use a first to file system, which would effectively block the appliance company from challenging a patent issued to another who was first to file, even if the appliance company was the first to invent. 
after the expiration of the patent, in either seventeen or twenty years. ${ }^{19}$ In light of these facts, if the company estimates that nobody else is likely to replicate its invention, then the company has no incentive to go through the trouble and expense of patenting. Rather, the company will keep the invention secret. If, however, the company estimates that a competitor, present or future, is likely to come up with a similar invention, the company will file for a patent to use as a barrier.

The appliance company's strategizing conforms to the argument put forth by Fritz Machlup that the disclosure-promoting effects of the patent system are minimal. Machlup argues that inventors will conceal whenever they can, regardless of the patent system, and that inventors will only patent inventions prone to discovery. ${ }^{20}$ F.M. Scherer and others have criticized Machlup's conclusion as oversimplifying the behavior of organizations by neglecting the risks inherent in secrecy. ${ }^{21}$ The primary risk Scherer identifies is the risk that another company will patent the same invention, thus foreclosing the original inventor from using his invention or fully appropriating the investment required to innovate. ${ }^{22}$ But even Scherer admits that the patent system promotes disclosure only in "borderline" cases. ${ }^{23}$ Furthermore, it has been argued that even where a firm attains a patent, "[i]t is well known that a firm tries not to disclose key parts of the invention in order to reduce the chance of imitation, thereby reducing the effective diffusion of knowledge."24 When Scherer's arguments are applied to the nonmanufacturing patent owner, however, the risk of foreclosure from using an invention poses no real threat. In the case of Schon's appliance company and Du Pont's color proofing process, the value does not arise from the ability to use the invention. Therefore, the risk Scherer identifies becomes negligible.

Why should we care about our hypothetical appliance company's strategies over whether or not to patent the food preservation invention? Because the appliance company, which is in the best possible position to

19. Until 1995, the term of a United States patent was 17 years from issuance. See 35 U.S.C. § 154 (1984). Pursuant to GATT, the term is now 20 years from date of application. See Act of Oct. 11, 1996, Pub. L. No. 104-295, § 20(e)(1), 110 Stat. 3529 (1996) (codified as amended at 35 U.S.C. § 154 (1997)).

20. See Study of the Subcommittee on Patents, Trademarks, and Copyrights of THE COMmitte on the Judiciary, U.S. SenAte, 85TH CONG., 2D SESS., AN Economic Review of the Patent System: Study No. 15, at 76 (Comm. Print 1958) (Fritz Machlup) [hereinafter Study of the Subcommittee on Patents]; see also F.M. Scherer et al., Patents and the Corporation: A Report on Industrial Technology Under Changing Public Policy 119 (2d ed. 1959) (describing the results of a survey of 91 corporations in which 29 of the 69 corporations stated that they would not patent where certain features of the invention could be kept secret).

21. See F.M. Scherer, lndustrial Market Structure and ECONOMic Performance 441 (2d ed. 1980).

22. See id.

23. Id.

24. William D. Nordhaus, 1nvention, Growth and Welfare 89 (1969). 
know about the development of the technology in its field, will only patent an invention it does not plan to commercialize when there is a threat that some other party will disclose the same technology within a relatively short period of time. Revealing the company's strategizing suggests that the grant of a limited monopoly right in exchange for some social benefit-what will be referred to here as the patent grant contract-is a bad bargam indeed.

II

\section{The Purposes of and Justifications for the Patent System}

The United States patent system serves the constitutionally mandated utilitarian purpose of "promot[ing] the Progress of Science and useful Arts."25 There are four theories that seek to explam how the patent system in fact promotes technology. Viewing these theories through the lens of contract law, ${ }^{26}$ we see that the incentive-to-invent theory and the incentive-to-disclose theory treat patents as "unilateral contracts," or rewards for mvention or disclosure. In contrast, both the incentive-toinnovate theory and the prospect theory view patents as more akin to "executory contracts," or bargains for commercialization or coordination activity yet to be undertaken by the patent owner.

In this section, I describe each of the four economic rationales for the patent system, discuss their relevance to the patent as a social contract, and assess their coherence in the context of the patent grant to the nonmanufacturing patent owner. ${ }^{27}$

\section{A. The Incentive-to-Invent Theory}

\section{Overview}

The incentive-to-invent theory deems patents necessary to encourage an optimal level of invention. ${ }^{28}$ Due to the ease with which

25. U.S. ConsT. art. $1, \S 8, \mathrm{cl} .8$.

26. As the Federal Circuit stated in Markman v. Westview Instruments, Inc.:

The analogy of a patent to a contract may appear to some extent to be an appropriate way of describing the circumstances surrounding the issuance of a patent. The inventor is required to make full disclosure of his invention to the Patent and Trademark Office (PTO) and to the public in his patent specification, which he is otherwise not obligated to do. In return, the law allows the government to confer a property right to exclude anyone else from making, using, or selling the invention covered by the claims for [the patent term], which it is otherwise not obligated to do.

52 F.3d 967, 984-85 (Fed. Cir. 1995) (footnote omitted) (alteration added), affd, 116 S. Ct. 1384 (1996).

27. Others also have used this structure to analyze proposed limitations on the scope of patents. See Rebecca S. Eisenberg, Patents and the Progress of Science: Exclusive Rights and Experimental Use, 56 U. Chi. L. Rev. 1017, 1024-46 (1989); Yusing Ko, An Economic Analysis of Biotechnology Patent Protection, 102 Yale L.J. 777, 791-804 (1992).

28. See Ward S. Bowman, Jr., Patent and Anttr rust LaW 2-3 (1973); Scherer, supra note 21, at 444. 
competitors can appropriate intellectual property, ${ }^{29}$ a monopoly is required to enable the inventor to recoup his costs and obtain a return on his risk of failure. ${ }^{30}$ By providing compensation for risk, the patent promotes additional inventive activity. ${ }^{31}$

The incentive-to-invent theory has been criticized most persuasively by F.M. Scherer, who argues that alternative incentives and protections play a far greater role in the decision to invent. ${ }^{32}$ Indeed, in a survey of ninety-one large corporations holding approximately one third of all U.S. patents in 1956, most companies indicated that patent protection was the least important factor in their R\&D investment decisions; considerations of relative competitive position were more important. $^{33}$ Furthermore, the survey indicated that a large portion of companies would readily forego patent protection if they believed they could keep certain characteristics of an invention secret. ${ }^{34}$ Since corporations undertake more inventive and patenting activity than individuals, and since corporations prefer trade secrets where they are available, the incentive-to-invent theory loses relevance as a justification for our patent system..$^{35}$

29. This is known as the "problem of appropriability," which perrvades all discussions of intellectual property. Because of the nature of intellectual property, which can be used nonexclusively and without limit, a creator of property may not be able to recoup his investment and a return when others simply copy his work. Various intellectual property legal regimes have been developed to solve this problem.

30. See SCHERER, supra note 21 , at 444.

31. See Eisenberg, supra note 27, at 1025-26; William F. Baxter, Legal Restrictions on Exploitation of the Patent Monopoly: An Economic Analysis, 76 YALE L.J. 267, 270 (1966).

32. See SCHERER, supra note 21 , at $444-46$ (discussing alternatives such as first-to-market advantage, the availability of trade secret protection, and the natural lag time involved in copying).

33. See SCHERER ET AL., supra note 20 , at 118.

34. See id. at 119 (showing that 29 of 69 eompanies, or $42 \%$, would forego patent protection where secrecy was an option).

35. Perhaps one reason for the disjunction between patent protection and the incentive to invent is the shift of inventive activity from small, independent inventors, who are not in a position to take advantage of alternative incentives, to corporate $\mathrm{R} \& \mathrm{D}$ divisions, which are in such a position. See JACOB SCHMOOKLER, INVENTION AND ECONOMIC GROWTH (1966) (noting the steady decline in the number of patent applications from individual and small company inventors). See also Rights of Employed Inventors: Hearings on H.R. 4732 and H.R. 6635 Before the House Subcomm. on Courts, Civil Liberties, and the Administration of Justice of the Comm. on the Judiciary, 97th Cong., 2d Sess. 12 (1982); David Stipp, Lab Legacy: Inventors Are Seeking Bigger Share of Gains from Their Successes, WALL ST. J., Sept. 9, 1982, at 1 (assessing the percentage of employed inventors at 75\%). Taking into account the relative incentive power of these alternatives and the shift in the locus of invention renders the incentive-to-invent theory a very weak justification for the patent system. See Study of The Subcommittee on PATENTs, supra note 20, at 62 (dceming any analysis of the relationship between patent law and incentives to invent "highly speculative"). Despite its weakness as a justification for the patent system, the incentive-to-invent theory strongly influenced the court in Du Pont. The court stated that if a patent owner could not rely on its patent to exclude others, the "research and development budgets in the science and technology based industries would shrink, resulting in the pnblic no longer benefitting from the labors of these talented people." $706 \mathrm{~F}$. Supp. 1135, 1146 (D. Del.), aff'd, 887 F.2d 1095 (Fed. Cir. 1989). 


\section{Implications of the Incentive-to-Invent Theory on the Value of the}

\section{Patent Grant Contract}

The incentive-to-invent theory defines the patent grant contract retrospectively, as a reward for work that has led to a successful invention. The benefit conferred upon society is the existence of the invention itself. Yet the existence of an invention provides insufficient economic justification for a monopoly. As noted by Joseph Schumpeter, credited with first distinguishing between invention and innovation, "As long as they are not carried into practice, inventions are economically irrelevant."36

To the extent that the availability of patent protection no longer supplies a strong incentive driving invention, society gets the worse of the bargain: society unnecessarily grants a monopoly where adequate alternative impetuses stimulate invention and where the mere existence of the invention fails to confer an economic benefit upon society.

\section{The Incentive-to-Invent Theory and the Nonmanufacturing Patent Owner}

The incentive-to-invent provided by the patent system probably influences the nonmanufacturing patent owner more than patent owners who commercialize, whose incentives come from potential profits to be realized through commercialization. The incentive-to-invent theory provides an "also ran" award to the R\&D-heavy corporation that chooses against commercializing some, or many, of its patents. The market-entry barrier aspects of the patent provide compensation for the costs of R\&D never recouped through commercialization. Traditionally, companies charged with patent misuse due to nonuse of patents have been these large, monopolistic, research-heavy entities. ${ }^{37}$ This is one reason why patent nonuse is an issue in antitrust cases. ${ }^{38}$

Nonetheless, empirical evidence demonstrates that no causal relationship exists between the quantity of research and development activity in which a firm engages, and the incentive of gaining monopoly power through the potential for patenting all inventions. Scherer's survey of ninety-one large corporations demonstrates that patent protection is the least influential factor in $\mathrm{R} \& \mathrm{D}$ decisions. ${ }^{39}$ In contrast, maintaining a competitive advantage, gained through first-to-market and other

36. Joseph A. Schumpeter, The Theory of EConomic Development 88-89 (Redvers Opic trans., Harvard Univ. Press 1951).

37. See, e.g., Hartford-Empire Co. v. United States, 323 U.S. 386 (1945); E.I. du Pont de Nemours \& Co. v. Polaroid Graphics Imaging, Inc. 706 F. Supp. 1135 (D. Del.), aff'd, 887 F.2d 1095 (Fed. Cir. 1989).

38. See, e.g., Zenith Radio Corp. v. Hazeltine Research, Inc., 395 U.S. 100 (1969); HartfordEmpire Co. v. United States, 323 U.S. 386 (1945).

39. See SCHERER ET AL., supra note 20, at 118. 
marketing strategies, constitutes the most influential factor in R\&D decisions. ${ }^{40}$

Although the nonmanufacturing patent owner fails to reap marketing benefits, research demonstrates that marketmg benefits nonetheless motivate research and development. For example, in a U.K. study of companies that shelved research and development projects for nontechnical reasons, all did so for post-development reasons, usually related to marketing priorities or difficulties. ${ }^{41}$ This study demonstrates that the choice not to use is frequently made ex post, after the results of various research projects are known, rather than ex ante, when research is initiated. Thus, even in the case of the nonmanufacturing patent owner, marketing benefits adequately motivate research and development, without the added incentives of a patent grant.

Finally, to the degree that the nonmanufacturing patent owner simply prohibits use of his invention, his patent becomes economically irrelevant ${ }^{42}$ and, as a barrier to entry, economically wasteful. Consequently, as an economic justification for the patent system, the incentive-to-innovate theory falls flat and inay even provide a perverse mcentive for firms to utilize the patent grant to generate market-entry barriers.

\section{B. The Incentive-to-Disclose Theory}

\section{Overview}

The incentive-to-disclose theory defends the patent system as promoting technological advancement through disclosure, informing others in the field about advancements made by colleagues and competitors. ${ }^{43}$ Disclosure also notifies others conducting research in the same area that the race is over and that they should divert their research dollars to other endeavors, including design-arounds. ${ }^{44}$ Disclosure requires patent protection to permit the inventor to appropriate the value of his invention in the face of now equally knowledgeable competitors. Society awards the patent monopoly for the benefit of dissemination of information.

The incentive-to-disclose justification weakens against the backdrop of trade secret protection. Trade secrets, unlike patents, have an

40. See id.

41. See Centre for the Study of lndustrial InNovation, supra note 14, at 9-24.

42. See infra note 51 and accompanying text.

43. To get patent protection, an applicant must disclose his invention with enough specificity to enable one ordinarily skilled in the relevant art to make and use the same. See 35 U.S.C. § 112 (1988).

44. See Edmund W. Kitch, The Nature and Function of the Patent System, 20 J. L. \& EcoN. 265,278 (1977). 
indefinite and potentially infinite duration. ${ }^{45}$ The effect of trade secret protection on patenting activity is evidenced by the disparity between the number of product and process patents, ${ }^{46}$ and patterns of expenditure on and patenting of internal processes. ${ }^{47} \mathrm{~A}$ comparison of the disparity in numbers between patents issued and expenditures on internal processes compels the conclusion that coinpanies are more likely to rely on trade secret protection for imternal processes, which, unlike commercialized products, are not subjected to public scrutiny and the potential for reverse engineering. Since disclosure is often an inevitable side effect of commercialization, patent protection is less useful as a mechanism to encourage disclosure than as a mechanism to enable commercialization.

Finally, the phenomenon of withholding key technologies from patent applications to further retard imitation, in spite of the "best mode" requirement, also reduces the effective diffusion of knowledge, the very benefit society seeks to gain in this bargain. ${ }^{48}$

\section{Implications of the Incentive-to-Disclose Theory on the Value of the Patent Grant Contract}

The incentive-to-disclose theory, like the incentive-to-invent theory, views the patent grant contract retrospectively, as a reward for an act done, namely the disclosure of some novel, useful and nonobvious invention. Again, this retrospective view is analytically weak in light of disincentives to disclose and the trade-off analysis in which most companies engage when determining whether to opt for patent or trade secret protection. To the extent that companies choose patent protection

45. Perhaps the most famous example is Coca-Cola's "secret formula" Merchandise 7X, which Coca-Cola Co. has maintained as a trade secret since 1899. See Coca-Cola Bottling Co. v. Coca-Cola Co., 107 F.R.D. 288, 289 (D. Del. 1985) (describing, in a suit that attempted to force the Coca-Cola Co. to disclose its secret formula pursuant to a protective order, the extent to which Coca-Cola Co. protected the formula), aff'd, 988 F.2d 414 (3d Cir. 1993); see also Coca-Cola Botding Co. v. CocaCola Co., 563 F. Supp. 1122, 1124 (D. Del. 1983) (placing the invention of Coca-Cola at 1886).

46. Note that there is a three-to-one ratio of product to process patents issued betwcen June 1976 and March 1977 to the 443 representative corporations surveyed by Scherer. See F.M. Scherer, InNovation and Growth: Schumpeterian PERSPEctives 35 (1984). This ratio is "[c]onsistent with prior surveys." Id. at 36.

47. A survey performed by Scherer reveals one indicator of this trend. According to the survey results, during 1974 fully $57 \%$ of the $R \& D$ expenditure of the manufacturing industries went toward processes to be used in the originating industry, while only $26 \%$ of patents issued were for internal processes. See id. at 36,51 .

48. See NoRDHAUS, supra note 24 , at 89 . The best mode requirement, 35 U.S.C. $\S 112$, requires the applicant to disclose the best mode, if any, of practicing the patent. Failure to disclose will invalidate the patent. Some argue that the best mode requirement prohibits patent owners from withholding invention-related trade secrets. However, the fact that the best mode requirement is effective only at the time of filing an initial application, coupled with the difficulty in discovering exactly when secret techniques were developed, tends to eviscerate the best mode requirement and foster secrecy. The net result is patents which do not enable commercializing use. 
chiefly where the invention's patentable properties ultinnately will be disclosed upon manufacture, sale, or use, society pays too high a monopoly price for disclosure.

\section{The Incentive-to-Disclose Theory and the Nonmanufacturing Patent Owner}

The reward-for-disclosure justification does not motivate the nonmanufacturing patent owner to disclose any more than it motivates patent owners who commercialize. Where the nonmanufacturing patent owner intends to use the patent as a barrier to entry, its incentive to disclose is driven by its estimate of when others are likely to generate a signiflcantly similar invention. If no competition is foreseeable on either the twenty-year horizon or, inore aptly, during the life cycle of the inventor's own competing product, then the inventor will choose not to patent. While the reward for disclosure may adequately inotivate some who are ambivalent about the choice between patenting and secrecy, ${ }^{49}$ the effect of the patent's reward for disclosure function is uncertain.

Conversely, the real benefit to be gained by disclosure, diffusion of the invention and the know-how required for impleinentation, inay be gleaned more readily from the commercialization of the invention, rather than the patent. ${ }^{50}$ Commercialization necessarily diffuses the information required to put the invention into practice due to the need to train production and engineering personnel who may later move on to employinent with other coinpanies. To the extent that the patent monopoly is used solely as a barrier to entry, the bargained-for disclosure may prevent realization of the inore valuable goal of diffusion.

\section{The Incentive-to-Innovate Theory}

\section{Overview}

The incentive-to-innovate theory may be traced back to the work of Joseph Schumpeter, who posits that while invention itself produces "no economically relevant effect at all,"51 innovation-the work necessary to bring an invention to market, including refinements, marketing, and investınent in capital goods_drives a dynamic inodel of capitalism characterized by a "process of Creative Destruction." 52 Under this dynamic inodel, monopoly conditions will proinote innovation and growth more effectively than competition by offering monopoly rents to

49. See SCHERER, supra note 21, at 441 .

50. As the Federal Circuit has noted, "[]]t is a rare invention that cannot be deciphered more readily from its commercial embodiment than from the printed patent." Paulik v. Rizkalla, 760 F.2d 1270, 1276 (Fed. Cir. 1985).

51. Joseph A. SChuMpeter, 1 Business Cycles 84 (1939).

52. Joseph A. Schumpeter, CAPITAlism, Socialism aNd Democracy 83 (3d ed. 1950). 
compensate for the risks of innovation, thus making it easier to attract investment to new technologies. ${ }^{53}$ Scherer applies Schumpeter's economic view of innovation to the patent system, ${ }^{54}$ describing the system as encouraging not just invention, defined as the "'act of producing or creating by exercise of the imagination," "ss but subsequent innovation, namely the "recognition of market needs; the organization of systematic product or process improvement, testing, production, and marketing efforts; the raising of essential capital; and assumption of the responsibility for deciding to go forward." Under the imcentive-to-innovate theory, the patent system promotes the riskier, resource-devouring innovation period.

A comparison of the incentive-to-invent and the incentive-tomnovate theories shows the waning of the former and the waxing of the latter. The incentive-to-mvent theory is most relevant where the patent owners are smaller imventors who benefit more than large corporations from a patent's power to attract investment, ${ }^{57}$ and who are less resistant than larger corporations to dramatic change..$^{58}$ Yet the incentive-tomvent theory holds less sway as the proportion of independent inventors to industrial inventors decreases while the importance of the incentiveto-innovate theory mcreases with the inarkedly rising costs of innovation. ${ }^{59}$ Even behemoths of industry have limited R\&D funds. Higher innovation costs bring greater risks, requiring bigger payoffs in the form of monopoly rents. ${ }^{60}$

53. See SCHUMPETER, supra note 36 , at 61-74.

54. See generally ScherER, INNOVATION AND GROWTH, supra note 46; SCHERER, INDUSTRIAL MARKET STRUCTURE, sUpra note 21.

55. F.M. Scherer, The Economic Effects of Compulsory Patent Licensing 7 (1977) (quoting the American College Dictionary).

56. Id. at 8 .

57. For an explanation of why this is so, see ScHERER, supra note 21, at 449.

58. For a discussion of the resistance of larger corporations to change, see Schon, supra note 17 , at $42-111$.

59. For an overview of the increase in development costs throughout this century and an explanation of the underlying reasons, see JOHN JEWKES ET AL., THE SOURCES OF INVENTION 15268, 212-17 (2d ed. 1969).

60. In addition to theoretical rationales in support of the incentive-to-innovate theory, additional support can be found in statements by the legislature and the judiciary. Congress has codified several pronouncements about the purpose of U.S. patent law which accord with the incentive-to-innovate theory. As recently as 1996, Congress declared that "[b]ringing technology and industrial innovation to the marketplace is central to the economic, environmental, and social well-being of the people of the United States." National Technology Transfer and Advancement Act of 1995, Pub. L. No. 104113, § 2, 110 Stat. 775 (1996) (codified at 15 U.S.C.A. § 3701 (West Supp. 1997)). In a predecessor act, Congress specifically declared it the "policy and objective of the Congress to use the patent system to ... protect the public against nonuse or unreasonable use of inventions." Bayh-Dolc Act, Pub. L. No. 96-517, § 6(a), 94 Stat. 3019 (1980) (codified at 35 U.S.C. \$ 200 (1988)). Thus even Congress, as the implententor of U.S. patent policy, recognizes that an overriding purpose of patent protection is the commercialization of patented technology, not just the disclosure or invention of it. The Federal Circuit has also propouuded the incentive-to-innovate theory on occasion. See, e.g., 
2. Implications of the Incentive-to-Innovate Theory on the Value of the Patent Grant Contract

Unlike the incentive-to-disclose and incentive-to-invent theories, the incentive-to-innovate theory views the patent system as prospective. Rather than perceiving the patent as a reward for work, or a deed done, the patent grants a form of bargaining power or subsidy to the patent owner that, in turn, generates innovation. Society gives a monopoly in return for the benefits to be reaped in the future when the technology is commercialized. Under this theory, both society and the patent owner stand to gain by commercialization, and to lose by suppression.

\section{The Incentive-to-Innovate Theory and the Nonmanufacturing Patent Owner}

The incentive-to-innovate theory breaks down arguments for protecting the patent rights of the nonmanufacturing patent owner. To the extent that the nonmanufacturing patent owner knows at the outset that it will not coinmercialize some or many of its patents, the incentive-toinnovate theory fails to justify the monopoly granted to this patent owner. It may be argued that nonmanufacturing patent owners have no way of knowing at the outset of research which inventions will be commercially successful and which will not, but such an argument presumes an intent to fully exploit all inventions insofar as they are commercially practicable. Moreover, no alleged infringers exist where an invention is commercially impracticable, and the issue remains moot. The innovation justification falters, however, when the patent owner has patented a technology which is commercially viable in some form but refuses to commercialize or license it. By continuing to protect the patent monopoly, society maintains a bargain that, paradoxically, deprives society of the bargain's main benefit: the commercialization of the technology. The nonmanufacturing owner's suppressive activity thus undermines the spirit of the bargain struck between society and the patent owner, and creates a situation in which infringing activity represents a more optinal outcome for society.

A counterargument is that the overall benefit of the patent system will be undermined by society's repudiation of the patent bargain. Violation of patents will introduce uncertainty and thus discourage patenting and the inventive activity leading up to it. Although there is some validity to this argument, it is overstated. By limiting the application of a doctrine of "efficient infringement" to those activities easily

Patlex Corp. v. Mossinghoff, 758 F.2d 594, 599 (Fed. Cir. 1985) ("[E]ncouragement of investmentbased risk is the fundamental purpose of the patent grant.") (emphasis added).

61. See infra Part III. 
delineated according to standards already available in patent law, the delicate patent system balance will not be npset. ${ }^{62}$

\section{The Prospect Theory}

\section{Overview}

Edward Kitch proposes a fourth economic theory to explain the extended nature of the patent grant. According to Kitch, the value of a patent arises from what he terms the "prospect function." Analogizing the mineral claim prospecting system to the patenting system, Kitch notes that the utility patent system does not simply reward past invention; a patent derives its valne from the prospect of future gain through government-guaranteed exclusivity. ${ }^{64}$ The prospect function of the patent system is necessary to ensnre appropriate allocations of investment in discovery. By assiguing property rights, the patent system fosters the most efficient use of $R \& D$ resources and the technology those resources yield.

Additionally, the patent system serves a prospect function by protecting novel, useful and nonobvious inventions that simply work, rather than only applying to inventions that have been developed to the point of commercial marketability. According to Kenneth Dam, the patent's early granting function serves an important economic purpose: it informs other researchers that the race is finished, thus preventing wasted resources and rent seeking. ${ }^{65}$ The patent system also fosters coordination of future development of the technology by forcing others wishing to use it to work with the patent owner, and by enabling the patent owner to freely and openly approach potential allies for joint exploitation of the patent without risking appropriation of the invention. ${ }^{66}$ These functions advance the dissemination of information, thus promoting the efficient allocation of resources by increasing knowledge.

\section{Implications of the Prospect Theory on the Value of the Patent Grant Contract}

As with the incentive-to-innovate theory, the benefit society receives from the cominercialization of technology constitutes an important component of the prospect theory. The efficient use of

62. For a discussion of the limiting principles proposed, see infra Part IV.

63. Kitch, supra note 44 , at 267.

64. See id. at 271.

65. See Kenneth W. Dam, The Economic Underpinnings of Patent Law, 23 J. Legal STud. 247, 262-66 (1994) (discussing the rent-seeking activity of research organs and how early filing incentives operate to minimize waste).

66. See Kenneth J. Arrow, Economic Welfare and the Allocation of Resources for Invention, in The Rate and Direction of INVEnTive Activity 609, 615 (National Bureau of Economic Research ed., 1962). 
research and development costs, afforded by forcing all researchers excluded by the patent to either divert their resources into something not yet discovered, or to coordinate with the patent owner, constitutes another benefit under the prospect theory. Thus, in exchange for a limited monopoly, society receives the efficient commercialization and exploitation of a given technology.

\section{The Prospect Theory and the Nonmanufacturing Patent Owner}

All arguments furnished by the prospect theory in support of the patent system fail in the context of a patent owner who refuses to innovate and refuses to coordinate. Underlying Kitch's prospect theory are assumptions of diligence and cooperation. ${ }^{67}$ The exclusivity guaranteed by the patent system is of value only when the patent is actually worked, and efficiencies are achieved when the patent owner cooperates with others who would improve upon the technology. Normatively, then, the patent system as a prospect system is not designed to permit value to be recovered through the intentional non-development of a patented technology. In Kitch's analogous context of mineral claims, refusal to work the claim may cause its forfeiture ${ }^{68}$ even though the ability of any one claim-holder to affect the price of his minerals by creating market shortage is limited.

Under both the prospect theory and the incentive-to-innovate theory, the main purpose of the patent system is not to reward invention but to enable innovation. Yet this most substantial justification of the patent system is undermined whenever a patent owner seeks patent protection to halt or forestall innovation of an invention and to prevent technological cooperation. Moreover, the nonmanufacturing patent owner also undermines the prospect theory's claim that patents foster the efficient allocation of resources; when patent owners acquire patents on several variations of a process, all performing a similar function, competitors are forced to spend even greater resources developing more design-arounds in spite of the fact that the patented design-arounds remam unused. If left unchecked, such pernicions "fencing" activity poses the greatest threat to the prospect and innovation functions of the patent system.

\section{E. Summary}

Of the four theories given for why we confer monopolies on inventors-(1) as an incentive to invent; (2) as an incentive to disclose; (3) as an incentive to innovate, and (4) as a way of reaping maximum

67. See Kitch, supra note 44 , at 274 (noting the requirement that mineral claims be worked in order to be kept in force).

68. See id. 
benefit with the most efficient funneling of resources-only the latter two stand out as strong justifications considering that the majority of modern inventive activity occurs within large, research-driven corporations. ${ }^{69}$

Since the incentive-to-innovate and prospect theories justify society's bargain on the grounds of what society stands to gain in the future from conferring a monopoly now, the refusal of a patent owner to commercialize, through licensing or manufacturing, eliminates the value of the monopoly bargain. In such instances, it may be more efficient for society to "breach" its bargain by refusing to perform its duty to provide injunctive relief for infringement.

III

\section{Promoting "EFFicient INFringement" Through THE USE OF LIABILITY RULES}

As the previous section denonstrates, the strongest economic justifications for an exclusionary patent system presume innovation and, where practicable, commercialization, to balance the social benefits with the social costs of granting a monopoly. What should be done where the patent owner's refusal to commercialize or to permit commercialization-due to irrational behavior, imperfect knowledge causing bargaining breakdown, or attempts to appropriate benefits without regard to harmful externalities such as limits on competition-deprives society of the benefit of its bargain? An analysis of this problem in the economic paradigm of property rules versus liability rules illuminates a path toward a theory of efficient infringement by demonstrating that the application of liability rules to the nonmanufacturing patent owner will yield greater efficiency. ${ }^{70}$

\section{A. The Property Rules/Liability Rules Distinction}

Property rules and liability rules are easily distinguished. Property rules both permit holders of entitlements to enjoin others from infringing upon their entitlements, and allow holders of entitlements to act without risk of liability. An example is the right of a landowner to evict trespassers, or to fell trees on his property that provide shade for his neighbor. In contrast, liability rules merely require one who causes damage to reimburse the victim in an amount equal to the actual harm caused. An example is permitting a factory to emit smoke, so long as the factory pays for any harm caused downwind. Patents are protected

69. See SCHMOOKLER, supra note 35 , at 26 .

70. The question of the relative superiority of property and liability rules was first discusscd in legal academia by Guido Calabresi and A. Douglas Melamed in their seminal article, Property Rules, Liability Rules, and Inalienability: One View of the Cathedral, 85 HARv. L. Rev. 1089 (1972). 
by property rules that permit the patent owner to enjoin infringers from further use.

Theoretically, where each party can ascertain the value of the other's entitlement, or the liability for harm done, and where both parties can bargain without impediment, an efficient outcome ${ }^{71}$ will result, regardless of who initially receives the entitlement or whether liability or property rules are used. ${ }^{72} \mathrm{~A}$ smoke-spewing factory operating next door to a commercial laundry provides a classic illustration. The smoke from the factory makes all the laundry smell bad. The launderer could install a filter at a cost of $\$ 100$ to block out the smoke. If the laundry has an absolute entitlement to clean air, a property rule entitlement, it may enjoin the factory from producing any smoke. If the factory earns more than $\$ 100$ from its activities, it will probably be able to negotiate a payment to the laundry of up to $\$ 100$, or the cost of the filter. If the factory earns less than $\$ 100$, it will not be worth its while to negotiate, and it will stop producing smoke. On the other hand, if the factory had an absolute right to make smoke, another property rule entitlement, the damage caused to the laundry is irrelevant to the factory. The launderer might approach the factory and offer up to $\$ 100$ to induce the factory to stop producing smoke. Again, if the factory's profits are less than $\$ 100$, it will take the deal. If the factory's profits exceed $\$ 100$, then the launderer will have to spend $\$ 100$ on a filter. If liability rules were applied to this situation, then the factory would be allowed to produce smoke, but would have to pay the launderer his damages, or $\$ 100$ for a filter. Again, if the factory earned more than $\$ 100$, it would choose to pay and pollute. If the factory earned less than $\$ 100$, it would not be worth its while to pollute, and would cease. In sum, whether property or liability rules are used, the most efficient outcome will be reached.

But achieving the most efficient outcome is not always a given. Impediments to bargaining, such as multiple parties, imperfect knowledge, or negotiation strategizing, may prevent an efficient outcome due to a breakdown in bargaining. Where impediments exist, liability rules will yield greater total welfare than property rules; liability rules permit action when efficient, when benefit exceeds harm, and discourage the same action when inefficient, when harm exceeds benefit. ${ }^{73}$ The greater

71. For purposes of this debate, an efficient outcome is that which maximizes social welfare by maximizing total benefits and/or minimizing losses.

72. This is simply a statement of the Coase theorem, which posits that "when transaction costs are zero, an efficient use of resources results from private bargaining, regardless of the legal assignment of property rights." RoBert COOTER \& ThoMAS ULEN, LAW AND EcoNomics 82 (2d ed. 1997) (summarizing the Coase theorem, implied in R.H. Coase, The Problem of Social Cost, 3 J.L. \& ECON. 1 (1960)).

73. For the full exposition of this argument, see Louis Kaplow \& Steven Shavell, Property Rules Versus Liability Rules: An Economic Analysis, 109 HARv. L. REv. 713 (1996). 
social welfare realized by applying liability rules in cases of bargaining impediments extends to real property.$^{74}$ Examples of the application of liability rules to real property rights include the doctrines governing the laws of takings and, more recently, laws of good faith improvers. I suggest that the noninanufacturing patent owner is another case where the application of liability rules will lead to a more efficient outcome. ${ }^{75}$

\section{B. Another View of the Cathedral}

Louis Kaplow and Steven Shavell have recently surmised that liability rules will increase social welfare more than property rules because liability rules will yield greater social welfare in both the absence of bargaining or in the presence of bargaining breakdown. ${ }^{76}$ This is particularly true where harmful externalities ${ }^{77}$ are present, in which case property rules will often result in inefficient use of resources due to imperfect bargaining. ${ }^{78}$

In spite of the superiority of liability rules, Kaplow and Shavell also assert that when it comes to the ownership of physical objects, property rules will produce greater social welfare. ${ }^{79}$ The existence of a common valuation for a "thing," as compared with the differing valuations of entitlements in the case of externalities, is the main reason liability rules cannot succeed in the case of the ownership of physical objects. Under liability rules, courts will tend to award damages approximating the average of the "common value" of a thing and the orvner's higher idiosyncratic value, thus undercompensating the owner. ${ }^{80}$ Since the owner's idiosyncratic value will exceed the court's averaged value as well as the idiosyncratic value placed on the thing by the person who takes it (the "taker"), liability rules will tend to permit lower-valuing takers to take. As a result, liability rules encourage takers to take inefficiently, leaving owners the prospect of paying off a series of potential takers to desist from taking.

74. For an economic analysis of the use of liability rules in the context of real property, see Stewart E. Sterk, Neighbors in American Land Law, 87 Colum. L. Rev. 55 (1987).

75. This same argument will hold true where a utilizing patent owner seeks to enjoin use of the technology in markets where the patent owner has no plans to expand. Sucli conduct may appear to be irrational in liglit of the potential for licensing revenues where no revenues would otherwise exist, but such conduct may occur as a result of bargain breakdown or irrational risk aversion, or may result when the patent owner is a conglomerate for whom almost all other industrial companies are competitors.

76. See Kaplow \& Shavell, supra note 73, at 735-37.

77. A larmful externality is a cost that the voluntary actions of one or more people impose on others without their consent. See COOTER \& ULEN, supra note 72, at 45.

78. See Kaplow \& Shavell, supra note 73, at 727.

79. See id; ; see also supra Part II.

80. See Kaplow \& Slıavell, supra note 73, at 759-62. 
For example, Owner owns a sofa. The sofa matches Owner's lamp and carpet very well; Owner is proud of this fact. Owner frequently has guests in her living room who admire her taste in design. Although the original price of the sofa was only $\$ 1000$, and its replacement value is $\$ 1000$, Owner would not sell the sofa for twice that amount. Taker, a thief, breaks into Owner's home and steals her sofa. Under the current property rule regime, Owner will ideally have her sofa returned. However, if a liability rule were applied, Owner could only sue Taker for damages. Owner will argue that the sofa is worth $\$ 2500$ to her. Taker will point to the original price and the price of a similar replacement sofa, both $\$ 1000$. The court might award something in between, perhaps $\$ 1400$.

Under liability rules, the people admiring Owner's sofa know that they may be able to take it for only $\$ 1400$. The admirers, if criminally disposed, will either take Owner's sofa and ransom it back to her, or make an up front deal whereby they agree to desist from taking if Owner pays them the difference between Owner's idiosyncratic valuation and the court's valuation, approximately $\$ 1100$.

Since the presence of multiple takers would force Owner to pay each potential taker the difference between the lower liability valuation and Owner's idiosyncratic valuation in order to prevent taking, Owner would be forced to pay out an amount greater than her valuation. In other words, if Owner decides to pay one admirer $\$ 1100$ to not take the sofa, and then several more takers approach Owner, the amount Owner would need to pay out will exceed her valuation of $\$ 2500$, and she will stop paying admirers to desist from taking her furniture. Thus bargaining under liability rules will not be in Owner's interest. Instead, Owner may spend exorbitant sums of money on systems to protect her sofa. Takers will take from Owner, and from one another, leading to socially undesirable takings and perhaps anarchy. ${ }^{81}$ Only by applying property rules will the owner ultimately have an incentive to bargain over her property. ${ }^{82}$

\section{Liability Rules, Property Rules, and Intellectual Property}

Kaplow and Shavell's observations about the use of property rules with tangible property apply to intellectual property as well. Indeed, the problem of appropriability, whereby property rights for intellectual work are needed to allow the creator to appropriate the value of that which she has created, fairly mirrors the problems that Kaplow and Shavell identify when property is subject to liability rules, namely

81. See id. at 765-69.

82. See id. at 767. 
multiple takings and overspending to protect property or maintain its secrecy.

However, several assumptions that underlie Kaplow and Shavell's conclusion are inapplicable to the nonmanufacturing patent owner. First, Kaplow and Shavell assume that a thing may be used or possessed by only one person at a time..$^{83}$ Although this may be true of physical objects, it is not true of intellectual property. As a result, the problem of repeat or serial takings and its discouragement of bargaining by owners does not apply to patent ownership, whereby the owner can theoretically sell to multiple potential takers. Indeed, the ability to sell to multiple takers is the premise of a nonexclusive license, a common approach to appropriating the value of patents. ${ }^{84}$

Second, Kaplow and Shavell assume common valuation; Owner's sofa has a common "sofa" value because of its utility as a sofa. Relatively fungible property is susceptible to this common valuation problem, resulting in undercompensation. By contrast, patents are, by statutory definition, novel and therefore unique. Different entities will capitalize on patented technology differently, perhaps in different industries, causing "uncommon" or differentiated valuation, similar to the differentiated valuation present in the face of externalities, which arises from the decoupling of benefit to the injurer and harm to the injured. 85

Third, Kaplow and Shavell assume that the owner will most frequently value his property more highly than the potential taker due to the idiosyncratic value he places on it. However, in contrast to physical objects, courts may not tend to underestimate the value of patents because patent values are, at least theoretically, the result of rational and quantifiable business choices, not of idiosyncratic preference. While it may be difficult to value a patent, particularly early in its life, this difficulty chiefly derives from probleins of future projection rather than from idiosyncratic propensity.

83. Kaplow and Shavell define the taking of a thing "primarily as an instance in which a person brings into his own possession a physical object that had been in another person's possession." Id. at 757 n.140.

84. A spokesperson for Texas Instruments, perhaps one of the more aggressive and successful patent licensers, said that in 1993 its patent licenses brought in about $\$ 521$ million. See Brenda Sapino Jeffreys, Attaining Peace by Preparing for a Litigation War: Texas Instruments Guards Its Patents Fiercely, RECORDER, Dec. 13, 1996, at 1. Note that the article reporting this information was itself subject to "licensing" to different users insofar as it also appeared in another paper, as The Enforcers, TEx. LAW., Dec. 9, 1996, at 1.

85. The classic example of differentiated valuation arising from externalities is the sparkspewing locomotive that sets fires on farms lining the tracks. Absent non-economic inccntives, the railroad company is unlikely to invest in modifications to prevent the fires that, although devastating to the farmer, are economically irrelevant to the railroad. 


\section{Property and Liability Rules: A Continuum}

Kaplow and Shavell's conceptualization of property and liability rules as running along a continuum is more useful in determining which rules should be applied to the problem of the nonmanufacturing patent owner. Property rules lie at both ends of the continuum by placing "damages" at either zero, thereby granting the entitlement to the defendant, or infinity, thus granting the entitlement to the plaintiff. In the latter case, the court implicitly holds that the harm to the plaintiff is such that he cannot be compensated with money alone. Liability rules, which value damages as equal to harm, lie in the middle. ${ }^{86}$ Since this is a spectrum, liability rules and property rules are at times indistinguishable. Furthermore, altering the basic formula of liability rules will yield stronger or weaker incentives in accordance with policy goals to increase social benefit. ${ }^{87}$

The distinction between harmful externalities and takings of things may also blur, further complicating any pure implementation of either property or liability rules. ${ }^{88}$ For example, when the hypothetical factory blows smoke into the air, it certainly creates a harmful externality, causing damage to the neighboring laundry. However, the factory's smoke can be recast as a taking: the taking of clean air or an easement. Kaplow and Shavell offer soine useful guidelines to distinguish between a taking and a harmful externality: takings involve common valuation and pose the problem of reciprocal or sequential takings, thereby justifying a property rule; harmful externalities are characterized by an independence of injurer benefit and victim harm, and by an absence of reciprocal takings, making liability rules preferable. ${ }^{89}$ This framework is useful because it identifies which type of rule, property or liability, yields greater social welfare.

\section{Deliberate Nonuse of a Patent and Harmful Externalities}

Both the independent valuation of a patent by an owner and by an infringer, and the nonexclusive nature of patent use, indicate that nonuse creates harmful externalities. As a result, in the context of nonuse, liability rules will tend to produce greater social benefits. In the case of the noninanufacturing patent owner, the decision to forego use indicates that valuation of the patent is based on nonuse, whereas the infringer's valuation of the technology derives from use. The valuation

\footnotetext{
86. See Kaplow \& Shavell, supra note 73, at 756.

87. See id.

88. See id. at 773.

89. See id.
} 
is not common, but rather independent. ${ }^{90}$ For example, if Schon's appliance company were to patent its alternative food preservation inethod, and then sit on the patent, the value the appliance company derives would be that of protecting its current refrigerator market and manufacturing facilities. To a newcomer to this industry, the value in use of the method would come from actually implementing and marketing it. The valuations of two potential users will be even more independent where the potential infringer serves a different market or field. Additionally, use by the infringer does not foreclose use, or nonuse, by the patent owner, thus avoiding the problem of reciprocal takings.

A patent owner's refusal to commercialize the patented technology creates harmful externalities. This supports a decision to apply liability rules to nonmanufacturing patent owners. First, the nonuse of patents prevents diffusion of technology and its concomitant know-how. As discussed above, the bare disclosure required to obtain the patent itself will often be insufficient to create social value ${ }^{91}$ or enable others to use the patented invention without any supplementary information. ${ }^{92}$ Through manufacturing, however, the patent owner perforins the important social function of disseminating knowledge about the invention and the data required to commercially produce it, and creates greater wealth through increases in consumer welfare. This diffusion of technology and know-how may also foster leap-frogging inventions-future improvements or mnovations inspired by today's technology. ${ }^{93}$ Second, the refusal to permit use forces potential users of the patented technology to design around the unused patent, resulting in waste. As noted by Scherer, "[T]he resources devoted to circumventing patents might, if inventions were made freely available, be allocated instead to alternative activities with higher increinental social payoffs. 994

The existence of externalities generated by nonuse supports a decision to apply liability rules to those who infringe against a nonmanufacturing patent owner. Although few would argue for the abolition of a patent system on economic grounds, the ex post application of liability

90. The same phenomenon of independent valuation occurs where the infringer is using the invention in a different industry and for a different purpose than the using patent owner.

91. See SCHUMPETER, supra note 36 and accompanying text.

92. See S.C. GILfILlan, INVENTION AND THE PATENT SYSTEM 61 (1964) ("'The information disclosed in patents is often not enough, taken by itself, to be of much use to the receiver."') (quoting Raymond Vernon, The Int'l Patent System and Foreign Policy, in STUdy of THE SuBCommitTeE on Patents, Trademarks and Copyrights of the Committee on the Judiciary, U.S. Senate, 84TH CONG., 1ST SESS. (1957)); NoRdhaus, supra note 24 and accompanying text; Barkev S. Sanders et al., Attitudes of Assignees Toward Patented Inventions, 2 PAT. TrademarK \& CopYright J. REs. \& EDUC. 463, 467-68 (1958) (presenting survey results suggesting that about one-half of patented inventions cannot be used without supplementary know-how).

93. See Peter S. Menell, Tailoring Legal Protection for Computer Software, 39 STAN. L. Rev. $1329,1337-38$ (1987) (discussing the interrelation between invention, innovation, and social benefits).

94. SCHERER, supra note 21 , at 446 . 
rules to an unused patent will permit "efficient infringement" by minimizing or eliminating the harmful externalities caused by nonuse, while permitting the patent owner to be compensated.

\section{Nonuse as Breach of Contract}

A separate arguinent for using liability rules arises from comparing the patent grant to a contract. Contracts are generally subject to liability rules. The application of damage awards for breach of contract tends to permit efficient breaches. Efficient breach occurs when the breaching party increases his profit despite having to compensate the nonbreaching party for lost profits due to the breacher's nonperformance. ${ }^{95} \mathrm{By}$ granting expectation damages, liability rules ensure that the breaching party will breach only when it is economically efficient to do so, that is, where the breach inaximizes surplus. For example, efficient breach by a buyer will occur when the buyer finds he is able to purchase the same product from a different seller at enough of a discount to permit him to both reimburse the seller his lost profits and still benefit from the breach. Efficient breach implies that the second seller can produce efficiently enough to create a surplus sufficient to compensate both the contract seller and himself.

In analogizing to the case of the nonmanufacturing patent owner, it is useful to think of the patent owner as a seller in a social contract. As discussed in Part II, the patent owner sells the fruits of his inventive work in the form of disclosure and a promise to innovate or coordinate innovation. In exchange, society, in the position of the buyer, grants the patent owner a time-limited monopoly. The patent contract is ongoing, requiring at least a twenty-year commitment of enforcement from society. It will be efficient for the buyer to breach this contract where another "seller" can generate enough surplus to cover the patent owner's damages and still turn a profit. Where expectation damages alone are the compensation, only surplus-generating infringers will continue to infringe; sellers other than the patent owner who cannot increase profit sufficiently to create a Pareto improvement $t^{96}$ will be unable to afford the breach price of the patent owner's damages.

Liability rules deter inefficient breachers who, by definition, create profits which are less than the damages caused to the injured party. By contrast, property rules deter both efficient and inefficient breachers by requiring all breachers to desist, regardless of any breacher's ability to compensate the injured party. Since liability rules already sufficiently

95. See A. Mrtchell Polinsky, An Introduction to Law and Economics 31-34 (1989).

96. Pareto improvement, also known as Kaldor-Hicks efficiency, occurs when change permits gainers to gain more than the losers lose, resulting in maximization of overall social welfare. See id. at 7 n.4. 
deter inefficient breachers, property rules only serve to deter efficient breachers. As a result, injunctive relief will have the effect of preventing only efficient infringements, where the infringing seller could fully compensate the patent owner and still create greater social welfare. Inefficient infringing sellers will not need an injunction to prevent them from infringing; damages alone will shut them down. In light of this, liability rules may promote greater social welfare when applied to the nonmanufacturing patent owner.

\section{E. Summary}

Nonuse of a patent defies the traditional economic justifications for patent monopolies. Applying liability rules to unused patents encourages efficient infringements, namely those which recoup to society the value to have been derived from the patent grant in the first instance. Society should use liability rules for property when doing so maximizes social welfare. In the case of the nonmanufacturing patent owner liability rules will create efficiency gains; inefficient infringements will be appropriately deterred.

Some may suggest that all patents, whether used or not, should be subject to liability rather than property rules because of the overall welfare-maximizing effect of liability rules and the potential for efficient infringeinent regardless of use by the patent owner. However, such an argument may overly discount the administrative costs associated with determining harm to the patent owner in every instance where a potential infringer believes he could put the patented technology to more efficient use. ${ }^{97}$ The technology underlying patents is inherently unique, belying any common, easily assessed market value. The courts must estimate not only current profits but all potential future profits, including those to be derived from the secondary effects of the patent monopoly: the market share, the effects of being first to market, the value of the monopoly, and the future opportunities. In light of the positive costs associated with determining whether a given infringement is efficient, limiting the availability of liability rules to cases of nonuse will help avoid wasted administrative costs.

\section{IV \\ A Proposed Judicial Solution}

The judiciary has the power to forego property rules in favor of liability rules in litigation involving a nonmanufacturing patent owner.

97. Patent litigation is one of the most expensive types of commercial litigation, with an average cost per suit of approximately $\$ 1$ million. See Mary Ann Tucker, Corporate Counsel's Role in Patent Litigation, in Practicing Law Institute: Patents, Copyrights, Trademarks, and Literary Property Course HaNdbook Series 279, 296 (1995). 
I propose that it do so where it finds a patent owner unwilling to use the patent or license it to others on fair and reasonable terms. A brief overview of patent litigation will clarify where the judiciary can most effectively apply liability rules in lieu of property rules.

\section{A. Overview of Patent Litigation}

In the normal course of a patent suit, the patent owner will sue the alleged infringer, seeking a permanent injunction ${ }^{98}$ and damages, which are trebled if the infringement was willful. ${ }^{99}$ The alleged infringer will defend on the grounds that he is not infringing and that the patent is invalid. The stakes on both sides are potentially enormous. As soon as possible, the patent owner will file for a preliminary injunction. Before granting a preliminary injunction, the court must balance four factors that the patent owner must show: (1) a reasonable likelihood of success on the merits; (2) irreparable injury if the preliminary relief is not granted; (3) that the balance of hardships tips in the patent owner's favor; and (4) that the issuance of a preliminary injunction favors the public interest. ${ }^{100}$ In patent infringement cases, courts grant preliminary injunctions about sixty percent of the time. ${ }^{101}$

The grant or denial of a preliminary injunction has a very powerful impact on settlement. ${ }^{102}$ Consequently, prevailing at the preliminary injunction stage can be as important as prevailing overall. Additionally, the Supreme Court's ruling in Markman v. Westview Instruments, Inc. ${ }^{103}$ held that the trial judge is to interpret patent claims. As a result, the preliminary injunction stage will likely become more crucial to the parties, as preliminary injunction hearings are coupled with "Markman hearings" delineating the scope of the patent.

Assuming there has been no settlement after the preliminary injunction and Markman hearings, the parties will engage in lengthy and

98. See 35 U.S.C. § 283 (1994), which permits patent owners to obtain injunctions against infringers. Although damages are available for past injury, an injuction is obviously desirable to prevent ongoing damage.

99. See 35 U.S.C. $\$ 284$ (1994).

100. See Smith Int'l, Inc. v. Hughes Tool Co., 718 F.2d 1573, 1578-79 (Fed. Cir. 1983); see also M.A. Cunningham, Preliminary Injunctive Relief in Patent Litigation, 35 IDEA 213, 215 (I995).

101. See Cunningham, supra note 100, at 231 ("[B]etween October 1, 1982 and December 3I, 1993, district courts granted preliminary injunctions in slightly over sixty-one percent of the cases involving patent infringement.").

102. See Marina T. Larson \& Stanley D. Ference, III, Injunctions in Patent Litigation, in Practicing Law Institute, supra note 97, at 243 ("Preliminary injunctions have been recognized as a very effective motivator of settlement discussions, and as such can be very valuable to a party who is willing to license an invention, as well as to a party who seeks exclusivity."); see also Douglas Laycock, The Triumph of Equity, 56 L. \& CONTEMP. ProBs. 53, 60 (1993) (describing a conversation between the author and a Chaneellor of the Delaware courts in which the Chancellor declared that almost all of his cases settle upon the granting or denial of the preliminary injunction).

103. 116 S. Ct. 1384 (1996). 
expensive discovery culminating in trial. Should the patent owner prevail, the court will assess damages against the infringer, ${ }^{104}$ and will likely enjoin the infringer from further infringing the patent. ${ }^{105}$ In no case will these damages be less than a "reasonable royalty."106 The court will also determine if the infringeinent was willful, justifying up to treble damages, ${ }^{107}$ or if this was an "exceptional case," allowing the award of attorney's fees. ${ }^{108}$ Even if the patent owner prevails, the patent owner may still enter into a licensing agreement with the infringer.

If the alleged infringer prevails because the patent owner fails to prove infringeinent, the case ends. If, however, the alleged infringer prevails because he is able to show that the patent is invalid for any of a variety of reasons, ${ }^{109}$ the patent becomes unenforceable as to any party. The patent owner's licensees inay then have cause to either refuse payment under their licenses or to cancel their licenses. The gates open for any potential competitor to use the technology disclosed in the now invalid patent without payment or license to the patent owner.

\section{B. Liability Rules as a Lever to Encourage Early Settlement}

Due to its potent impact on any patent hitigation, the preliminary injunction stage is the first and most influential point at which the judiciary could put an efficient infringement doctrine into effect. In order to get a preliminary injunction, the patent owner must demonstrate, among other things, that it will suffer irreparable harm should an injunction fail to issue. ${ }^{110}$ The patent owner's ability to show a likelihood of success on the merits on the issue of infringement, coupled with the patent's presumption of validity, gives rise to a presumption of irreparable harm. The presumption of irreparable harm "simply acts ... as a procedural device which shifts the ultimate burden of production on the question of irreparable harm onto the alleged infringer." "If the patent owner's case for infringement is weaker, the patent owner must affirmatively show the likelihood that it will suffer irreparable harm.

Where the patent owner has a weak case for infringement, the Federal Circuit has been willing to consider use of the patent in determining whether irreparable harm would be suffered absent an

104. See 35 U.S.C. $\$ 284$ (1994).

105. See 35 U.S.C. $\$ 283$ (1994).

106. See 35 U.S.C. $\$ 284$ (1994).

107. See id.

108. See 35 U.S.C. $\$ 285$ (1994).

109. These reasons range from failing to satisfy all of the requirements of patentability (nonobviousness, novelty and utility), usually due to the discovery of some prior art, to fraudulent conduct before the patent offiee.

110. See supra text accompanying note 101 .

111. Reebok Int'1 Ltd. v. J. Baker, Inc., 32 F.3d 1552, 1556 (Fed. Cir. 1994) (citing Roper Corp. v. Litton Sys., Inc., 757 F.2d 1266, 1272 (Fed. Cir. 1985)). 
injunction. In High Tech Medical Instrumentation, Inc. v. New Image Industries, ${ }^{112}$ a nonmanufacturing patent owner with a weak infringement case was unable to ward off an appellate attack on its preliminary injunction. In overturning the injunction, the Federal Circuit declared, "Although a patentee's failure to practice an invention does not necessarily defeat the patentee's claim of irreparable harm, the lack of commercial activity by the patentee is a significant factor in the calculus." $" 113$

Even where the patent owner makes a strong showing of infringement, the alleged infringer may still introduce evidence that the patent owner will not suffer irreparable harm. As the Federal Circuit indicated in Roper Corp. v. Litton Systems, Inc..$^{114}$

The presumption does not change the ultimate equitable showing needed to justify a preliminary injunction. Like most legal presumptions, it is rebuttable by clear evidence that it is overcome in the case at hand. The presumption merely requires that an alleged infringer confronted by a patentee's strong showing of validity and infringement bring forward evidence that irreparable injury would not actually be suffered by the patentee if the motion for preliminary injunction were denied. ${ }^{115}$

Furthermore, injunctive relief is equitable relief, and preliminary injunctions may be withheld for a variety of equitable reasons. ${ }^{116}$

Currently, the courts are willing to accept that a patent owner can suffer injury through loss of an economic advantage generated by a product in competition with the infringing product. In Rite-Hite Corp. v. Kelley Co., the Federal Circuit permitted a patent owner to recover for lost sales of a product in the same line as the infringing device. ${ }^{117}$ Yet as the discussion in Parts II and III demonstrate, the nonuse of a commercially viable patent deprives society of the benefit of its patent grant contract and should not be enforced to the same extent as used patents. As a result, the harm caused by infringement to a nonmanufacturing patent owner's competing product is neither legally cognizable nor addressable. Such harm shonld be unable to support a finding of irreparable injury sufficient to justify injunctive relief.

The Federal Circuit has hinted that this might be a feasible way to deal with nonworked patents at the preliminary injunction stage. In

112. 49 F.3d 1551 (Fed. Cir. 1995).

113. Id. at 1556 .

114. 757 F.2d 1266 (Fed. Cir. 1985).

115. Id. at 1272.

116. See Smith Int'1, Inc. v. Hughes Tool Co., 718 F.2d 1573, 1581 n.7 (Fed. Cir. 1983) (“[I]n cases where equitable or public policy considerations are in favor of the infringer, a movant would have to make a stronger showing of irreparable harm in order to tip the balance of equity in his favor.").

117. Rite-Hite Corp. v. Kelley Co., 56 F.3d 1538, 1544-49 (Fed. Cir. 1995). 
Roper, the Federal Circuit did not state that nonuse eliminated the availability of injunctive relief, but rather decided that a nonmanufacturing patent owner would carry a greater burden to establish irreparable harm "by showing [for example] that an existing infringement precludes his ability to license his patent or to enter the market." 118 In other words, the patent owner would have to show that the infringement precluded the patent owner from working his patent, a showing which would require proof of at least bona fide attempts to use.

Ideally, denying a preliminary injunction will foster settlement in the form of a license. Should the denial of a preliminary injunction be imsufficient to engender successful settlement bargaining between the nonmanufacturing patent owner and the alleged imfringer, the courts nay next consider denying both permanent injunctive relief and treble damages. The nonmanufacturing patent owner's remedy would be limited to actual lost profits or a reasonable royalty. This model represents the adoption of a straight liability rule, the exact approach taken by the court in Allied Research Products, Inc., v. Heatbath Corp. ${ }^{119}$ The court found that defendant Heatbath infringed Allied Research's patent, yet refused to enjoin Heatbath from further use, declaring, "Public policy requires liberal use of a patent. An owner of a patent cannot assert his rights under the law and Constitution if such owner refuses to make use of a patent, or to license a patent so that it may be of use to the public, or refuses to license an applicant when it has already granted a license to the applicant's competitor." ${ }^{\prime 20}$ Instead, the court awarded the plaintiffs a reasonable royalty.

Although the decision in Allied Research is the exception and not the rule, recent decisions at least recognize the discretion of the trial court to refuse to grant injunctive relief in light of equitable considerations. ${ }^{121}$ To avoid inefficient infringement, though, the courts must take care not to undervalue the patent owner's lost profits, even at the risk of occasional overvaluation. Thus courts must consider secondary factors such as the impact of infringement on market share and on future opportunities.

Finally, how will the court recognize the nonmanufacturing patent owner who should be denied injunctive relief? Part I proffered several reasons why a patent owner may not be manufacturing. It will be important for a court to differentiate between a patent owner who is not manufacturing because his development or capitalization time is longer

\footnotetext{
118. Roper, 757 F.2d at 1273 .

119. 300 F. Supp. 656 (N.D. Ill. 1969).

120. Id. at 657 .

121. See, e.g., Kearns v. Chrysler Corp., 32 F.3d 1541, 1551 (Fed. Cir. 1994) (“'E]ntitlement to an injunction implementing the right to exclude, as compared with only assessing damages against an infringer, is not absolute even during the life of a patent, but is discretionary.").
} 
and one who fails to manufacture in order to use the patent defensively, as a market entry barrier. Such differentiation should not be overly difficult, and could even be patterned on the line of inquiry currently pursued by courts determining diligence in first-to-invent/last-to-file cases, namely by looking to whether the patent owner is taking reasonable and diligent steps toward commercializing the patented technology. ${ }^{122}$ Such steps could include reasonable offers to license, attempts to gather capital, or efforts to perfect the manufacturing processes necessary to produce a product embodying the technology.

\section{CONCLUSION}

The courts have struggled to determine the rights of the nonmanufacturing patent owner. Currently, the pendulum has swung far to one side: injunctive relief is granted almost mechanically on the presumption that remedies at law will always be insufficient in patent infringement cases. Proponents of this perspective argue that near-automatic injunctive relief will best serve the patent system in the long run. This Comment has argued that issuing injunctions in the case of the nonmanufacturing patent owner serves neither the long-term interests of the patent system nor of society, and, from an economic perspective, may disserve both. The courts should reconsider the knee-jerk dispensation of injunctions in patent infringement cases in light of the purposes of the patent system and how they are best promoted.

At a time when R\&D-intense corporations control a growing lion's share of all patents issued, we can expect to see more often patents used solely as barriers to market entry. While forcing others to design around a patent may produce benefits by increasing inventiveness, such benefits can be outweighed by the economic inefficiency of having to design around one or more unused patents. Yet some corporations will engage in this practice, regardless of the greater costs to society as a whole.

There is no reason why the patent system need be an accomplice to this hypercompetitive nonuse. The most persuasive and relevant justifications of goverument-granted patent monopolies presume that the patent is only one step along a road to use, be it commercial or academic. Surely when the framers of the Constitution einpowered Congress to grant monopolies to "promote the progress of science and the useful arts," 123 they did not envision the beneficiaries of this grant would use it to bury new technologies to protect market share or capital investments.

Economic theories also do not justify the automatic grant of injunctive relief in the case of the nonworked patent. Whether considered

122. See Mahurkar v. C.R. Bard, Inc., 79 F.3d 1572, 1577-79 (Fed. Cir. 1996); Griffith v. Kanamaru, 816 F.2d 624, 625-26 (Fed. Cir. 1987).

123. U.S. CoNST. art. I, $\S 8$, cl. 8 . 
in light of the relative inerits of property and liability rules, or analogized to a contract between the patent owner and society, nonuse of a patent should not be perpetuated where society stands to reap the benefits of the technology and the patent owner can be adequately compensated. 